\title{
The efficiency of dryland farming in Panggang Forest KPH Yogyakarta
}

\author{
Suhartono, Eva Fauziyah*, and Ary Widiyanto \\ Agroforestry Technology Research and Development Institute, Ciamis, Indonesia
}

\begin{abstract}
Dryland farming is still to be a main activity of the community around the part of Forest Area (Bagian Daerah Hutan/BDH), Panggang, Kesatuan Pengelolaan Hutan (KPH) Yogyakarta. This study aimed to determine the efficiency of dryland farming and the factors that influencefarming income. The survey method was used to carry out farming data and information by interview the farmer. The R/C analysis, labor productivity analysis, and capital productivity analysis were used to determine the efficiency of dryland farming. Furthermore, to determine the effect of production input factors on farming efficiency, a multiple linear regression analysis was carried out. The results showed that dryland farming by the community around BDH Panggang forest was not efficient because the value of $\mathrm{R} / \mathrm{C}<1 \quad(0,44)$, labor productivity $\mathrm{Rp}$ $29.522,69 /$ working people's day is lower than a local standard wage Rp $50.000 /$ working people's day, and the productivities of land and capital are negative value. The factors production, land area, seed cost, fertilizer cost, pesticide cost, and labor have simultaneously impacted the farmers' income for dryland farming. The factors of seed cost have been a significant effect on the farmers' income in dryland farming.
\end{abstract}

\section{Introduction}

Limited natural resources in the GunungKidul area make some people in the area do not have many choices in farming activities. Therefore, dryland farming is the most widely used field of employment by farming communities in the area. However, it is not uncommon for GunungKidul residents to go outside areas such as Yogyakarta and Jakarta to make a living other than farming. Yet according to [1], dryland has considerable potential and opportunity to produce food if it is managed with the right strategy and technology. However, these opportunities are often overlooked for reasons of technical constraints. Furthermore Dyah [2] explained that the use of dryland is a solution to the reduction in paddy fields due to land conversion.

The people of GunungKidul are known for their tenacity in managing marginal land. The condition of the agricultural area which is dominated by rocks makes farmers have to work hard in cultivating the land. This has been proven by farming communities in the

* Corresponding author: fauziyah_eva@yahoo.com 
GunungKidul area who always adhere to the principle of soil conservation in their farming activities. Natural conditions have changed behavior and increased farmers' awareness of the need for conservation efforts. The community realizes that protecting the land from erosion is very helpful in maintaining the cultivated area which is the main capital in farming. Abdurrachman et al. [1] explained that landslides and erosion are some of the obstacles in dryland agriculture. Therefore, soil conservation on dryland needs to be done as an effort to optimize land functions to increase farmers' productivity and income [3].

Many studies stated that labor and fertilizer are the most important production factors. However, in dryland farming activities in GunungKidul, land, and fertilizer are the most important production input factors apart from seeds and labor. This is in accordance with what was stated by [2] that land is a major factor in agricultural production activities. The condition of the land in GunungKidul which has a fairly thin soil solum requires more additional fertilizer because the organic content in the soil is very limited. Therefore, improving soil quality through additional nutrients, both organic and inorganic, is needed to increase dryland productivity [4,5]. These input factors are quite important and affect the productivity of the resulting farm. Therefore, the efficient use of $\backslash$ production inputs, both technical and financial, is needed to obtain optimal farming income.

This study aims to determine the efficiency of dryland farming carried out by the community around the BDH Panggang KPH Yogyakarta forest and the influence of production input factors on farming income.

\section{Method}

This research was conducted in Gunung Kidul Regency with the object of research on dryland farming carried out by the community around the BDH Panggang KPH Yogyakarta forest. The main data in this research are farmer cost and income during one year of farming. Some crops cultivated by the farmer under teak or eucalyptus stands are paddy, corn, bean, and cassava. The data was collected by interviewing 31 dryland farmers around BDH Panggang forest which were selected purposively. The data collection technique was carried out throughstructured interviews using a questionnaire. Furthermore, the data were analyzed descriptively.

To determine the level of efficiency of dryland farming, the $\mathrm{R} / \mathrm{C}$ analysis approach and business productivity (land productivity, labor productivity, and capital productivity) were used $[6,7,8]$.

Total Revenue $=$ TotalProduct $\mathrm{x}$ Price

Net Revenue $=$ Total Revenue - Total Ekplisit Cost

(1)

$\mathrm{R} / \mathrm{C}=\frac{\text { TotalRevenue }}{\text { Total ast (Ekplisit \& implisit) }}$

Labor productivity $=\frac{\text { Net Revenue }- \text { Rent walue of own land }}{\text { Number of the family workforce (labor') }}$

Land productivity $=\frac{\text { Net Revenue }- \text { Cost of Family Labor }}{\text { Large of farmland }}$

Capital productivity $=\frac{\text { TotalRevenue-Total cost }}{\text { Total cost }} \times 100$

Dryland farming carried out by the community around the BDH Panggang KPH Yogyakarta forest is considered efficient if 1) has a revenue ratio value compared to costs higher than 1,2) results in higher labor productivity than the applicable wage standards in the area, 3) produces land productivity that is higher than the standard land rental price, and 4) results in highercapital productivity from saving money services in the bank.

Furthermore, to assess the effect of production inputs tofarm income, the multiple linear regression analysis approaches is simplified into natural logarithms: 
$\operatorname{LnY}=a+b 1 \operatorname{LnX} 1+b 2 \operatorname{LnX} 2+b 3 \operatorname{LnX} 3+b 4 \operatorname{LnX} 4+b 5 \operatorname{LnX} 5+e$

(7)

Where:

$\mathrm{Y}=$ revenue from dryland farming, $\mathrm{X} 1=$ area of arable land, $\mathrm{X} 2=$ cost of seed procurement, $\mathrm{X} 3=$ cost of fertilizer procurement, $\mathrm{X} 4=$ cost of pesticide procurement, $\mathrm{X} 5$ = number of family workers, and e = error.

\section{Result and discussion}

\subsection{Characteristics of dryland farming around forest areas}

Respondents in this study consisted of $60 \%$ men and $40 \%$ women, with an average age of 49 years. Most of the respondents' last education was elementary school graduates. Almost $90 \%$ of respondents have a main job as a farmer and a side job as a farm laborer $(60 \%)$. Most of the respondents are local residents who have lived since birth. Most of the respondents have worked as farmers since their marriage, either on private land or state land. The average farmer's land ownership is 0.7 ha. The average farmer has about 28 years of farming experience. From the description of the characteristics of these respondents, it can be seen that the farmers in the research location are already quite experienced in managing dry land, especially on state land..

There are two types of trees that dominate namely teak and eucalyptus with an amount of about $69 \%$. The community utilizes the land under teak and eucalyptus stands by planting various types of agricultural crops, especially rice, corn, cassava, beans and soybeans. Apart from these edible agricultural crops, farmers in KPH Yogyakarta also plant grass, which is a source of their livestock feed.

Based on the main tree, there are two cropping patterns practiced by farmers, namely the teak-plant and eucalyptus-plant combination. The main difference is that intercropping under eucalyptus has a much longer duration than intercropping under teak stands. Intercroping under eucalyptus has much longer duration because eucalyptus leaves are harvested regularty so that the canopy doesnot overshadow the crop underneath.Intercropping under teak stands lasts only until the teak is about 3 (three) years old. If the teak is already large with a tight canopy, the intercropping activity is not possible to be carried out under it. Therefore, after the teak is 3 years old, the farmers leave the location and look for a new location that is still empty with the approval of the KPH, or wait until the teak is harvested and the farmers look for other jobs in both the agricultural and non-agricultural sectors.

Farmers start the planting season at the beginning of the rainy season which is around October, with the land preparation period in September. They generally can only do two planting activities to adjust the availability of rainwater, especially in the GunungKidul Regency area which has less rainfall than other areas in the KPH Yogyakarta. The most widely practiced combination cropping patterns are teak/eucalyptus - corn, teak/eucalyptus - corn and peanuts, teak/eucalyptus - teak/eucalyptus - corn and cassava, teak/eucalyptus rice. Rice generally can only be planted once during the first growing season, which is between October-February. Furthermore, the land is planted with secondary crops, especially maize and cassava.

Agricultural products are used to meet the daily needs of farmers. Rice is stored and used as the main food source. Almost all of the corn and peanuts are sold and used to buyside dishes and other necessities. Some of the cassava is sold, some areused for fodder in the dry season and some is consumed either directly or processed into tiwul. 


\subsection{Productivity of dryland farming}

In general, the dryland farming activities of the community around the BDH Panggang forest are still subsistence. The cultivation of dryland around the forest area is carried out using an intercropping system with the dominant staple plant being teak. The spacing for teak wood at the research location is $3 \mathrm{~m} \times 2 \mathrm{~m}$.

Most of the seasonal crops are used to meet the family's consumption needs, while the yields of timber are used to meet long-term needs, such as building houses and education costs.

Table 1. Productivity of dryland farming

\begin{tabular}{|c|c|c|c|c|c|c|}
\hline \multirow{2}{*}{$\begin{array}{c}\text { No. } \\
1\end{array}$} & \multirow{2}{*}{$\begin{array}{l}\text { Description } \\
\text { EkplisitCost: }\end{array}$} & \multicolumn{2}{|c|}{ Volume/unit } & \multirow[t]{2}{*}{ Cost (Rp) } & \multirow[t]{2}{*}{ Productivity } & \multirow[t]{2}{*}{ Remark } \\
\hline & & & & & & \\
\hline & $\begin{array}{l}\text {-Seed } \\
\text { Sed }\end{array}$ & 1 & Package & $296.887,09$ & & \\
\hline & -Fertilizer & 1 & Package & $779.306,45$ & & \\
\hline & -Pesticide & 1 & Package & $11.871,74$ & & \\
\hline & ImplisitCost: & & & & & \\
\hline & -own land rent & 0,31 & $\mathrm{Ha}$ & $616.129,03$ & & \\
\hline & $\begin{array}{l}\text {-family workface } \\
\text { (labor) }\end{array}$ & 49 & $\mathrm{HOK}$ & $2.450 .000,00$ & & \\
\hline 2 & Total Cost & & & $7.220 .323,35$ & & \\
\hline 3 & Total Revenue & & & $3.150 .806,45$ & & \\
\hline 4 & Net Revenue & & & $2.062 .741,16$ & & \\
\hline 5 & $\mathrm{R} / \mathrm{C}$ & & & & 0,44 & Not feasible \\
\hline 6 & $\begin{array}{l}\text { Farming } \\
\text { productivity: }\end{array}$ & & & & & \\
\hline & -land productivity & & & & - & Not feasible \\
\hline & -labor productivity & & & & $29.522,69 / \mathrm{HOK}$ & Not feasible \\
\hline & -capital productivity & & & & - & Not feasible \\
\hline
\end{tabular}

Remark: HOK = working people's day

In dryland farming activities, the costs paid directly are dominated by expenditures for the provision of production inputs such as seeds, fertilizers, and pesticides. The means of producing land and labor become farmers' capital which can be provided without paying cash. Apart from using their land, some farmers also obtain forest land use rights from the $\mathrm{KPH}$ Yogyakarta. Meanwhile, the workforce who does farming activities can still be fulfilled by family members so there is no need to pay outside wages. Thus, the cost of farming that must be paid is only the cost of procuring seeds and fertilizers as well as additional medicines if needed.

The results of dryland farming are dominated by food crops such as rice, maize, peanuts, and cassava. There are also a small number of farmers who have started cultivating kimpul tubers. The average farmer ownership ranges from 0.31 ha with a cash crop cost of Rp1,088,065.29 per year. Every year farmers get average farm revenue of IDR $3,150,806.45$ with income from cash costs of IDR 2,062,741.16. This condition is not much different from the income of dryland farming in Bakti Village, Pulubala, Gorontalo, which is around IDR 7,198,748 / ha or 2,231,611 / 0.31 ha [9].

Financially, farmers have obtained positive income because they do not pay cash for land rent and pay for farm laborers. However, if it is calculated from the total cost (cash and non-cash), farmers have not benefited from their farming. This is presumably because the level of efficiency in the use of production factors in dryland is not optimal, such as farming in wetlands. Several cases of research results also state that farming in wet or rainfed land tends to be more efficient than dryland farming [10]. The level of soil fertility on dryland, which is generally low, results in the use of production inputs that tend to be high so that it has an impact on farming costs[11]. 
The results of the comparison between the revenue and costs of dryland farming (Table 1) obtained an $\mathrm{R} / \mathrm{C}$ number of 0.44 which indicates that dryland farming by the community around the BDH Panggang forest is not yet feasible. The R/C figure of 0.44 illustrates that for every Rp1, - the capital allocated by farmers for dryland farming is only able to generate $\mathrm{Rp}$ 0.44. Thus, farmers have not yet benefited from the allocated capital in their farming activities. The farming conditions are slightly different from the intercropping farming in other areas in GunungKidul which has good prospects because it can generate positive income $[12,13]$.

The labor productivity of Rp.29,522 / HOK indicates that being a farmworker on one's own land has not been properly paid because the wages earned are smaller than the applicable standard wages in that area, which is Rp. 50,000 / HOK. Therefore, looking for work as a farm laborer in another place is more attractive than working on one's own land because it has the opportunity to get a higher wage. Thus, running dryland farming on one's own land is still not a viable business option when assessed by a financial approach. The prevailing land rental price at the research site is Rp. 2,000,000 per ha or Rp. 616,129 per $0.31 \mathrm{Ha}$. The average yield of dryland farming productivity is known to be negative.

This shows that the decision to cultivate one's own land for dryland farming is inaccurate if the farming objectives are profit-oriented. However, until now the farmers around BDH Panggang forest are still running their farms because the farming activities that are carried out are still subsistence.

\subsection{Farming efficiency}

The effectiveness of the capital used in farming activities is still far from what is expected. A negative profitability value indicates that dryland farming activities run by farmers have not provided financial benefits. Thus the decision to save money in the bank is more profitable than investing money in dryland farming activities.

Based on the ratio of revenues and costs, labor productivity, land productivity and capital productivity resulting from dryland farming, the business is not feasible to run because it is not economically efficient. However, farmers still get a positive income if implicit costs such as own lend rent and labor family are not counted as farming costs. Financially, the cash capital expenditures that are poured into dryland farming still produce benefits that are greater than the value of these expenditures. However, the income earned has not been able to pay the wages of family work and land rent according to the prevailing wage and land rent standards. The farming conditions may be different from other places which are economically feasible and profitable. Likewise, the productivity and efficiency of farming implementation can vary between locations and between commodities [14]. This can occur due to several factors, one of which is the difference in farming characteristics from one region to another. In several studies, it is also stated that the characteristics of farming influence the farm income generated. Another study states that the characteristics of farming, both the internal conditions of the farmers and the production facilities used influence farm income[15-17] although in certain cases these differences in characteristics do not significantly affect farmers' income [18].

\subsection{Effect of production input on farming revenue}

Dryland farming carried out by the community around the BDH Panggang KPH Yogyakarta forest has not been profit-oriented. Most of the productsgenerated from farming activities areused to meet their own needs. Therefore, the selection of plant species to be cultivated is still oriented towards food plant products. As for the long-term needs, farmers also plant types of wood with agroforestry cropping patterns as hedges. 
Table 2. Effect of production inputs on dryland farming income by communities around the BDH Panggang forest KPH Yogyakarta

\begin{tabular}{|l|c|c|c|c|}
\hline Production input variable & $\begin{array}{c}\text { Parameter } \\
\text { value }\end{array}$ & Standarddeviation & t-calc & P-value \\
\hline Constanta (b0) & 7,404 & 1,835 & 4,033 & 0,000 \\
\hline Large of land (b1) & 0,127 & 0,146 & 0,872 & 0,391 \\
\hline Seed cost (b2) & 0,303 & 0,122 & 2,479 & 0,020 \\
\hline Fertilizer cost (b3) & 0,127 & 0,138 & 0,921 & 0,365 \\
\hline Pesticide cost (b4) & 0,006 & 0,026 & 0,256 & 0,799 \\
\hline Number of labor (b5) & 0,251 & 0,184 & 1,360 & 0,185 \\
\hline R-square & 0,532 & & & \\
\hline F-calc & 5,685 & & & \\
\hline
\end{tabular}

All of the productionfactors, costs of procuring seeds, fertilizers, and pesticides as well as the number of workers together have a significant positive effect on the level of income of dry land farming. Itsshown by the f-count value of 5.685 which is greater than f-table 2.53 at the level of $=0.05$. However, when viewed partially, only the number of workers has a significant effect on farm income (t-count $2.479>\mathrm{t}$-table 1.677). The $\mathrm{R}$-square value of 0.532 illustrates that the variation of dry land farming revenue can be explained by $53.2 \%$ by five production variables and the remaining $46.8 \%$ is influenced by other variables outside of production factors.

Land production facilities are the main capital in farming activities. Likewise in dryland farming by communities around BDH Panggang forest, land requirements are obtained from their own land or land in the KPH Yogyakarta. In dryland farming activities, farmers do not incur costs for land acquisition or lease because the land used is their own land and or KPH Yogyakarta land. The land factor has a positive effect on the level of farm acceptance, although it is not significant. Whereas in the case of several studies, it was stated that the land factor had the most influence on production in dryland farming activities [10, 14, 19].

The need for other production facilities such as seeds and fertilizers is also important in farming activities. Some farmers around the BDH Panggang forest already have sufficient knowledge and experience in farming. This can be seen from their level of awareness in using quality seeds, especially for food crops such as rice, beans and corn. Likewise the use of fertilizers and drugs, in general, farmers have used fertilizers in a balanced way by using organic and inorganic fertilizers. Pesticides are used in relatively small portions. Most farmers only use pesticides only to kill grass during land clearing. The three input input factors of production have a positive influence on farm income. However, only the seed input factor has a significant effect on the level of farmer acceptance. The coefficient of 0.303 means each additional cost of $100 \%$ will increase farm revenue by $30.3 \%$. Thus, farmers still have the opportunity to increase their farm income by increasing the cost of procuring superior seeds.

The labor factor also has a positive effect on farmers' income, although it is not significant. The amount of labor expended in dryland farming tends to be excessive. This can happen because the labor used comes from their own families so that farmers do not consider it as farming costs. In addition, dryland farming activities are still carried out with low technology. Limited land area and farming objectives that are not yet profit-oriented are one of the reasons for not using agricultural technology equipment. Therefore, the workforce involved in farming is only dominated by family workers. Farmers still have the opportunity to increase family income by managing working time. Apart from working on 
their own land, farmers can look for other jobs so that their working time is not spent on their own land.

The dryland farming conditions carried out by the community around the BDH Panggang forest are slightly different from dryland farming in other places. Several research results stated that the factors of seeds, fertilizers, pesticides, and labor had a negative effect on farm productivity [19, 20, 21]. However, there are also research results which state that production factors such as seeds, fertilizers, pesticides, and labor have a positive effect on the resulting production[14,1 0]. This is very likely to occur due to differences in the characteristics of farming land, climate, and types of commodities, technology and management applied to each farming unit.

So that dryland farming is feasible and can provide benefits for farmers, not only subsistence, then there are several strategies that can be done. Among them are increasing the quantity and quality of commodities, increasing the amount of production, expanding the market, increasing capital, handling pests and diseases, and also increasing the role of farmer groups in facing market competition [22]. Farmers do have to do a strategy to make a profit. In Chile farmers in dryland areas reduced high-risk cropping activities after the recent drought shock by choosing crops with shorter growth periods and lower capital and technological costs, such as cereals. This means that farmers are working to develop crop adaptation strategies for dealing with drier environments in the future [23].

\section{Conclusion and recommendation}

\subsection{Conclusion}

Dryland farming by community in BDH Panggang Forest KPH Yogyakarta it is not economically efficient because based on the ratio of revenues and costs, labor productivity, land productivity and capital productivity resulting from dryland farming is not feasible. Dryland farming by the community is still subsistence and not profit-oriented. In general, this farming can generate positive income for farmers. However, financially, the farming is not yet feasible. The input factors for the production of cultivated area, the cost of procuring seeds, fertilizers, pesticides and the number of family workers together have a positive effect on the acceptance of dryland farming. However, only the cost of seed procurement has a significant effect on farmers' income.

\subsection{Recommendation}

It is better if the subsistence farming paradigm has begun to be abandoned and switched to agribusiness-oriented farming.Farmers should plant types of crops that have high economic value and market-oriented. To increase the income of dryland farming, farmers can increase the allocation of costs for procuring superior seeds and reduce the use of fertilizers and family labor.

Acknowledgement. We would like to acknowledge Balai Penelitian dan Pengembangan Teknologi Agroforestri and Dinas Kehutanan Provinsi Yogyakarta who facilitate this research.

\section{References}

1. A. Abdurachman, A. Dariah, and A. Mulyani, J. Litbang Pertan. 27, 43 (2008)

2. P. S. Dyah, in Pros. Interdiscip. Postgrad. Student Conf. 3rd. Progr. Pascasarj. Univ. Muhammadiyah Yogyakarta (PPs UMY) (2017), pp. 274-278 
3. M. Yusuf, Bul. Nutr. Dan Makanan Ternak. 14, (2020)

4. A. Kasno, J. Sumberd. Lahan. 13, 27 (2019)

5. X. Wang, Z. Jia, L. Liang, Y. Zhao, B. Yang, R. Ding, and J. Nie, F. Crop. Res. 218, 11 (2018)

6. A. Rahim, S. Supardi, and D. R. D. Hastuti, Model Analisis Ekonomi Pertanian (Universitas Negeri Makasar Press, Makasar, 2012)

7. R. Lestari, I. N. A. Ervina, and B. S. Triwara, 83 (2018)

8. G. D. Sumarno, Kelayakan Usaha Budidaya Bunga Krisan Petani Anggota Asosiasi Tanaman Hias Bunga Dan Daun Di Kecamatan Pakem, Kabupaten Sleman, Skripsi. Universitas Muhammadiyah Yogyakarta, 2016

9. F. Yunus, Z. Abidin, and D. Xyzquolyna, Agropolitan. 5, 28 (2018)

10. M. Ismail, A. Fariyanti, and A. Rifin, Forum Agribisnis. 7, 21 (2017)

11. A. Mulyani and M. Syarwani, in Pros. Semin. Nas. Lahan Sub-Optimal "Intensifikasi Pengelolaan Lahan Sub-Optimal Dalam Rangka Mendukung Kemandirian Pangan Nas. (Palembang, 20-21 September 2013, 2013)

12. H. Ginting and A. Astuti, Agritas. 2, 1 (2019)

13. G. Samidjo, S. Sarjiyah, H. Haryono, and R. Gustami, PLANTA Trop. 6, 9 (2018)

14. P. Y. Silitonga, S. Hartoyo, B. M. Sinaga, and I. W. Rusastra, Inform. Pertan. 25, 199 (2018)

15. N. Dewi, M. Utama, and N. Yuliarmi, E-Jurnal Ekon. Dan Bisnis Univ. Udayana 6, 701 (2017)

16. U. Maramba, J. Ekon. Pertan. Dan Agribisnis. 2, 94 (2018)

17. D. Chaerani, J. Embrio. 11, 23 (2019)

18. A. B. Santoso, J. Ilmu Pertan. Indones. 22, 108 (2017)

19. M. Fauzan, Agrimor. 5, 45 (2020)

20. D. Adar and M. Bano, J. Excell. 9, 93 (2020)

21. M. S. Lalu and Syuryawati, J. Pengkaj. Dan Pengemb. Teknol. Pertan. 20, 81 (2017)

22. W. Rahayu, U. Barokah, and R. U. Fajarningsih, J. AGRISEP Kaji. Masal. Sos. Ekon. Pertan. Dan Agribisnis. 19, 207 (2020)

23. F. Zúñiga, M. Jaime, and C. Salazar, Water Resour. Econ. 34, 1 (2021) 